\title{
Martwicze zapalenie tkanek miękkich krocza imitujące ropień okołoodbytowy - opis przypadku
}

\section{Necrotizing fasciitis of perianal soft tissue mimicking perianal abscess - a case report}

\author{
Andrzej Żyluk ${ }^{\bowtie}$, Wojciech Jagielski, Zbigniew Szlosser \\ ${ }^{1}$ Pomorski Uniwersytet Medyczny w Szczecinie, Klinika Chirurgii Ogólnej i Chirurgii Ręki, ul. Unii Lubelskiej 1, 71-252 Szczecin \\ Pomeranian Medical University in Szczecin, Department of General and Hand Surgery \\ $\bowtie$ azyluk@hotmail.com
}

\begin{abstract}
A case of necrotizing fasciitis of perianal soft tissue mimicking perianal abscess is reported. The clinical presentation of this case in terms of extent and course might be considered a mild form of Fournier gangrene. The condition developed in a 65-year-old woman, burdened with no comorbidities, within 5 days, causing necrosis of perianal soft tissue and sepsis. The

ABSTRAKT

Opisano przypadek martwiczego zapalenia tkanek miękkich okołoodbytowych imitującego ropień okołoodbytowy, którego rozległość i przebieg kliniczny mogły odpowiadać łagodnej formie zgorzeli Fourniera. U nieobciążonej dodatkowymi chorobami 65-letniej pacjentki choroba rozwinęła się w ciągu 5 dni, powodując martwicę okołoodbytowych tkanek miękkich i uogólnione zakażenie. Miejscowy wygląd zmian przypominał ropień
\end{abstract}

appearence of local lesions mimicked bilateral perianal abscess. Operative treatment by wide incisions of the affected perianal areas, evacuation of necrotic debris and antibiotic infusions was successful, but required repetition, and closure of the skin defect around the anus and at the buttock required local flap plasty. Keywords: perianal abscess; necrotizing fasciitis; Fournier gangrene. umiejscowiony po obu stronach odbytu. Leczenie operacyjne przez rozległe nacięcie zmienionej zapalnie okolicy, ewakuację tkanek martwiczych i antybiotykoterapię było skuteczne, ale musiało być powtarzane, a zamknięcie ubytku skóry na pośladku w okolicy odbytu wymagało plastyki płatowej.

Słowa kluczowe: ropień okołoodbytowy; martwicze zapalenie powięzi; zgorzel Fourniera.

\section{WSTĘP}

Ropień okołoodbytowy powstaje wskutek zakażenia gruczołów okołoodbytniczych, które w liczbie 4-8 są rozmieszczone wokół kanału odbytu, w mięśniu zwieraczu wewnętrznym lub w przestrzeni między zwieraczami, a ich ujścia dochodzą do krypt odbytowych, na wysokości linii grzebieniastej (zębatej). Zatkanie ujścia jednego z gruczołów hamuje odpływ śluzu, co sprzyja namnażaniu się flory bakteryjnej i prowadzi do wytworzenia ropnia. Zakażenie wywołane jest najczęściej bakteriami kałowymi: E. coli, Streptococcus faecalis i Bacteroides fragilis. Ropnie okołoodbytowe są stosunkowo częste; występują 3-krotnie częściej u mężczyzn niż u kobiet, a czynnikami sprzyjającymi ich powstawaniu są cukrzyca, stany osłabienia odporności i choroba Leśniowskiego-Crohna [1].

Martwicze zapalenie powięzi (łac. fasciitis necroticans) to ropny stan zapalny rozprzestrzeniający się wzdłuż powięzi i powodujący martwicę okalających tkanek miękkich (mięśni i podskórnej). Etiologia jest typowo paciorkowcowa, choć (rzadziej) może być to także gronkowiec złocisty. Występuje przede wszystkim na kończynach, a powodem są zaniedbane rany i otarcia naskórka [2]. Specyficzną formą martwiczego zapalenia powięzi obejmującego okolicę krocza (zewnętrznych narządów płciowych i odbytu) jest tzw. zgorzel Fourniera. Zakażenie wywołują bakterie wprowadzone do tkanki podskórnej wskutek (zwykle drobnego) urazu, ale także pochodzące z układu moczowego lub z odbytnicy. Infekcja szerzy się w obrębie przestrzeni międzypowięziowych, wywołuje martwicę narządów płciowych, krocza i ściany jamy brzusznej, prowadzi do posocznicy i jest obarczona wysoką śmiertelnością. Inaczej niż w martwiczym zapaleniu powięzi o lokalizacji kończynowej w zgorzeli Fourniera flora bakteryjna jest bardziej zróżnicowana, o etiologii jelitowej, tlenowa i beztlenowa [3, 4]. Zgorzel Fourniera częściej dotyczy mężczyzn niż kobiet, a czynniki sprzyjające jej powstaniu to cukrzyca i stany osłabienia odporności (immunosupresja, choroba nowotworowa, alkoholizm, nosicielstwo HIV). Zdarza się rzadko, szacunkowo 1 przypadek na 8 tys. hospitalizacji. Blisko 1/3 przypadków zgorzeli Fourniera dotyczy noworodków i niemowląt poniżej 3. miesiąca życia [3].

W pracy opisano przypadek martwiczego zapalenia tkanek miękkich imitującego ropień okołoodbytowy, którego rozległość i przebieg kliniczny mogły odpowiadać łagodnej formie zgorzeli Fourniera. 


\section{OPIS PRZYPADKU}

W kwietniu 2017 r. do Kliniki Chirurgii Ogólnej i Chirurgii Ręki Pomorskiego Uniwersytetu Medycznego w Szczecinie przyjęto 65-letnią, dotychczas zdrową kobietę, z powodu rozległego ropnia okołoodbytowego. Podczas przyjęcia chora skarżyła się na silny ból obu pośladków w okolicy odbytu, gorączkę wynoszącą $39^{\circ} \mathrm{C}$ oraz dreszcze. Dolegliwości zaczęły się 5 dni przed przyjęciem i stopniowo nasilały się. W wywiadzie nie było żadnej choroby sprzyjającej. Stan ogólny był średnio ciężki, $\mathrm{z}$ wyraźnymi objawami uogólnionego zakażenia $\left(\mathrm{t}=39,2^{\circ} \mathrm{C}\right.$, dreszcze, RR 100/60). W badaniu przedmiotowym stwierdzono rozległy naciek zapalny w przyodbytowej części obu pośladków z powierzchowną martwicą skóry. Palpacyjnie naciek miał twardą konsystencję i nie wyczuwało się chełbotania. Zmiany nie były symetryczne; naciek na prawym pośladku był bardziej rozległy, a bolesność uciskowa była wyczuwalna także nad odbytem w okolicy guzicznej, co sugerowało łączność obu patologii.

Parametry stanu zapalnego były znacznie podwyższone: liczba leukocytów wynosiła 25 G/L, stężenie CRP 376 mg/L, a stężenie prokalcytoniny $6,2 \mathrm{~g} / \mathrm{L}$, co wskazywało na rozpoczynającą się posocznicę. Stężenie glukozy było nieznacznie podwyższone do $160 \mathrm{mg} / \mathrm{dL}$. W badaniu USG stwierdzono rozległy naciek zapalny i obrzęk tkanki podskórnej po obu stronach odbytu, z obecnością licznych pęcherzyków gazu, ale bez widocznych zbiorników płynowych, co sugerowało podejrzenie martwiczego zapalenia tkanek miękkich. W dolnej części prawego pośladka była widoczna przestrzeń hypoechogeniczna o wymiarach $5 \times 4 \mathrm{~cm}$, położona ok. $4 \mathrm{~cm}$ pod powierzchnią skóry, mogąca być naciekiem lub ropniem.

\section{PIERWSZA OPERACJA}

Wobec takiego obrazu klinicznego podjęto decyzję o pilnym leczeniu operacyjnym. Przed zabiegiem podano dożylnie 1,2 g amoksycyliny z klawulonianem i 1 g metronidazolu. Operację przeprowadzono w znieczuleniu ogólnym, w ułożeniu ginekologicznym. Nacięto skórę i tkankę podskórną nad wyczuwalnym naciekiem zapalnym po obu stronach odbytu, ewakuując treść posokowatą i rozpadające się tkanki martwicze, a po stronie prawej także treść ropną. Martwica sięgała głęboko (7-8 cm) w tkanki miękkie okołoodbytnicze, tak że ściany odbytnicy

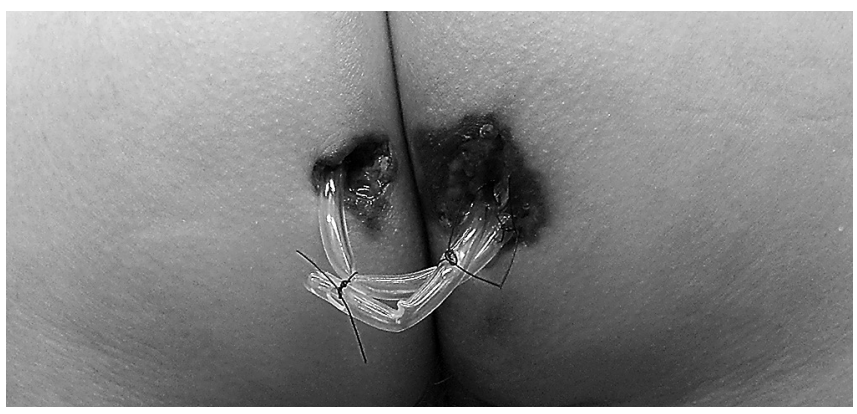

RYCINA 1. Stan miejscowy w 2 dni po nacięciu ropowicy były wyczuwalne przy jej usuwaniu palcem. Naciek zapalny przechodził nad okolicę guziczną, tak że obie zmiany łączyły się tam ze sobą. Przepłukano powstałą jamę roztworem antyseptycznym i założono jeden dren, przeprowadzając go nad okolicą guziczną (ryc. 1).

\section{PRZEBIEG POOPERACYJNY}

Po operacji kontynuowano dożylną antybiotykoterapię: amoksycylinę z kalwulonianem $3 \times 1,2 \mathrm{~g}$ i metronidazol $3 \times 0,5 \mathrm{~g}$. Przebieg pooperacyjny był pomyślny i następnego dnia po operacji stan ogólny chorej wyraźnie się poprawił. Od 2. doby pooperacyjnej wprowadzono do leczenia laktulozę $3 \times 15 \mathrm{~mL}$ doustnie, żeby pacjentka regularnie się wypróżniała. Natomiast stan miejscowy tkanek w okolicy odbytu nie ulegał poprawie: postępowała martwica skóry, którą systematycznie wycinano, a z jamy po wyciętych tkankach ewakuowała się treść ropna i posokowata, którą odsysano i płukano roztworem antyseptycznym (ryc. 2). Badanie bakteriologiczne uzyskane w 2. dobie po operacji wykazało zakażenie bakteriami E. coli wrażliwymi na wszystkie antybiotyki testowane w antybiogramie. W 4. dobie pooperacyjnej wykonano ponowny posiew, który wykazał zakażenie kilkoma drobnoustrojami: E. coli, Enterococcus faecalis i mieszaną florą mikroaerofilnych, co było powodem zmiany antybiotyków na ciproflaksacynę $3 \times 0,2 \mathrm{~g}$ i amikacynę $2 \times 0,5 \mathrm{~g}$ dożylnie, zgodnie $\mathrm{z}$ antybiogramem. W 7 . dobie pooperacyjnej zdecydowano o ponownym oczyszczeniu rany.

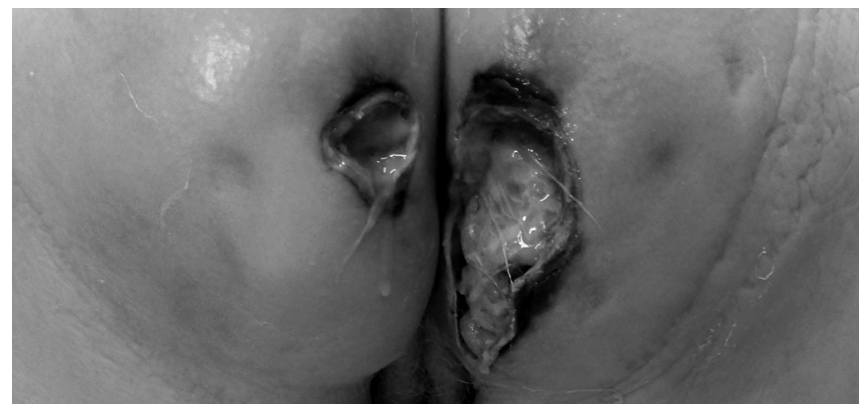

RYCINA 2. Stan miejscowy w 5. dobie leczenia, przed drugą operacją

\section{DRUGA OPERACJA}

Operację wykonano w znieczuleniu ogólnym, w warunkach bloku operacyjnego i ułożeniu na brzuchu. Poszerzono poprzednie cięcia, ewakuowano ponownie dużą ilość martwiczych tkanek z jamy wokół odbytnicy i z pośladków. Wypłukano obficie jamę, usunięto dren i w jego miejsce wprowadzono wilgotny seton nasycony płynem antyseptycznym (ryc. 3). Przebieg pooperacyjny po drugiej operacji był pomyślny. Chorej zalecono wykonywanie 2 razy dziennie nasiadówek w wodzie z mydłem, dzięki czemu zmniejszył się wyciek treści i rana zaczęła się goić. W 15. dobie po przyjęciu pacjentkę wypisano w stanie dobrym do leczenia ambulatoryjnego, z niezagojonymi ranami 


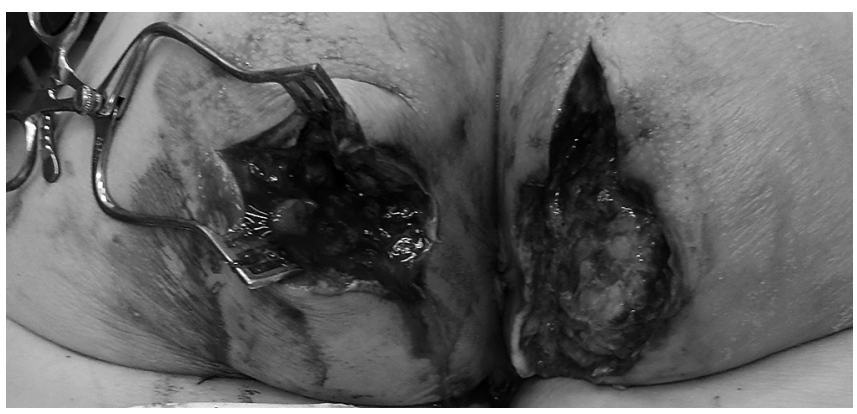

RYCINA 3. Obraz śródoperacyjny przy 2. operacji

w okolicy odbytu i ubytkiem skóry na prawym pośladku. Zalecenia poszpitalne dotyczyły kontynuowania nasiadówek, dbania o higienę ran i regularne wypróżnienia.

\section{TRZECIA OPERACJA}

Po 2 tygodniach od wypisania chorą ponownie przyjęto do kliniki w celu zamknięcia ran i pokrycia ubytku skóry. Rany w okolicy odbytu były czyste i uległy wyraźnemu zmniejszeniu. Ubytek skóry na prawym pośladku miał wielkość $15 \times 5 \mathrm{~cm}$ (ryc. 4). Planowano zszycie ran i pokrycie ubytku skóry przeszczepem pośredniej grubości. Operację przeprowadzono w znieczuleniu ogólnym, w ułożeniu na brzuchu. Zszyto ranę na lewym pośladku, a na prawym pośladku udało się zamknąć ranę, wykonując plastykę płatową, bez konieczności użycia przeszczepu (ryc. 5). Przebieg pooperacyjny był niepowikłany i ostatecznie, po 6 tygodniach od rozpoczęcia leczenia uzyskano zagojenie ran i wyleczenie chorej.

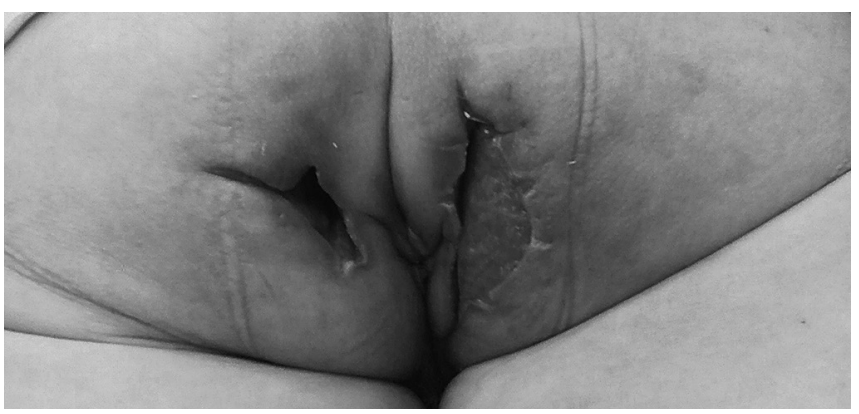

RYCINA 4. Ubytek skóry okołoodbytowy po ustąpieniu stanu zapalnego

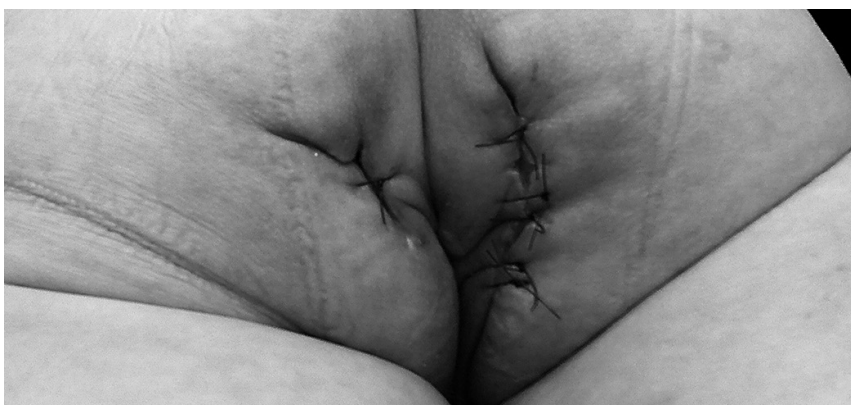

RYCINA 5. Zszyta rana po nacięciach ropowicy

\section{OMÓWIENIE}

Opisywany przypadek jest intersujący przez swoje podobieństwo do ropnia okołoodbytowego. Wydaje się jednak, że faktycznie było to martwicze zapalenie tkanek miękkich okołoodbytniczych spowodowane bakterią E. coli. Przemawia za tym rozległość stanu zapalnego: zajęcie tkanek po obu stronach odbytu i nad kością guziczną, przewaga martwicy tkanek nad procesem ropnym, szybki rozwój zakażenia z odczynem ogólnoustrojowym - posocznicą i współistnienie martwicy skóry w okolicy nacieku zapalnego. Taki obraz kliniczny może wskazywać na łagodną postać zgorzeli Fourniera. Martwicze zapalenie powięzi (także w formie zgorzeli Fourniera) występuje zwykle u chorych z cukrzycą i w stanach osłabienia odporności, a opisywana pacjentka była dotychczas zdrowa i nie miała żadnych problemów z odpornością. Przyczyną powstania zakażenia tkanek miękkich krocza mógł być pierwotnie ropień okołoodby towy, choć taka ewolucja tego schorzenia u osoby bez zaburzeń odporności jest wyjątkowo rzadka. W trakcie leczenia obawiano się o możliwość martwicy ściany odbytnicy, co pogorszyłoby rokowanie i wymagało wyłonienia czasowej kolostomii; na szczęście do tego nie doszło.

W piśmiennictwie znaleziono jeden podobny przypadek. Bednarek i Drożdż opisali przebieg leczenia 59-letniej chorej przyjętej do szpitala z powodu rozległej ropowicy krocza oraz martwicy skóry w okolicy pośladków i odbytu. Pacjentka chorowała na cukrzycę insulinozależną i w przeszłości miała kilkakrotne epizody zakażenia tkanek miękkich. Przy przyjęciu była w ciężkim stanie, z rozwiniętą posocznicą. W trakcie operacji, po wycięciu martwiczej skóry stwierdzono, że zgorzel obejmuje tkankę podskórną, a także mięśnie pośladków i penetruje głęboko do dołów kulszowo-odbytniczych, w przestrzenie powięziowe miednicy małej. Wykonano rozległe wycięcie zakażonych tkanek, ale zakażenie rozprzestrzeniło się na prawą kończynę dolną, co wymagało jej wysokiej amputacji. Z pobranego materiału wyhodowano bakterię E. coli, wrażliwą na większość antybiotyków. Pomimo intensywnego leczenia chora zmarła w 6 dni po przyjęciu z objawami niewydolności wielonarządowej [4].

Gołąb i wsp. opisali wyniki leczenia 13 chorych o średniej wieku wynoszącej 58 lat ze zgorzelą Fourniera o podłożu „urologicznym". U każdego zidentyfikowano przynajmniej jeden czynnik sprzyjający: złe warunki higieniczne z powodu ubóstwa, cukrzycę lub uzależnienie alkoholowe. Okres od wystąpienia objawów do ustalenia rozpoznania wynosił średnio 4 dni. W ponad połowie przypadków przyczyną choroby było powierzchowne uszkodzenie skóry krocza lub zabieg medyczny. Najczęstsze objawy to ból, obrzęk i martwica tkanek okolicy moszny, rzadziej prącia i powłok brzusznych. Wszystkich chorych operowano, wykonując rozległe wycięcie martwicy, nacięcie powięzi (fasciotomię) i drenaż, a u 3 dodatkowo ustalono cystostomię. Siedmiu chorym usunięto jądro, w tym 4 - obustronnie. U większości pacjentów z posiewów wyhodowano mieszaną florę tlenową i beztlenową. Po operacji stosowano antybiotykoterapię, zwykle kilkulekową. Rany pooperacyjne prowadzono „na otwarto”. Trzech chorych (23\%) 
zmarło, a kilku wymagało operacji rekonstrukcyjnych w celu zamknięcia ran [5].

Opisywane są także ciężkie przypadki martwiczego zapalenia powięzi o etiologii paciorkowcowej w obrębie kończyn. W jednej z publikacji autorzy opisują posocznicę o etiologii paciorkowcowej u starszej kobiety, do którego doszło w następstwie drobnej rany na ręce. U chorej początkowo rozpoznano zespół ciasnoty przedziałów powięziowych, który leczono miejscowym nacięciem powięzi. Pomimo to zakażenie postępowało, rozwinęła się posocznica i nastąpiła konieczność amputacji kończyny, choć pacjentka przeżyła [6]. W klinice autorów leczono 74-letnią chorą obciążonej licznymi chorobami towarzyszącymi, w tym cukrzycą, u której w ciągu kilku dni od powierzchownego zranienia ręki doszło do rozległej martwicy tkanek miękkich całej kończyny górnej, a następnie do posocznicy o etiologii paciorkowcowej. Pomimo radykalnego leczenia chirurgicznego i antybiotykoterapii rozwinęły się powikłania ogólnoustrojowe, których nie dało się opanować, i chora zmarła [7].

\section{PIŚMIENNICTWO}

1. Żyluk A. Zakażenia chirurgiczne. In: Żyluk A, editor. Zarys chirurgii. Podręcznik dla studentów i lekarzy w trakcie specjalizacji. Warszawa: Medipage; 2016.

2. Cheng NC, Su YM, Kuo YS, Tai HC, Tang YB. Factors affecting the mortality of necrotizing fasciitis involving the upper extremities. Surg Today 2008;38:1108-13.

3. Rosen DR, Brown ME, Cologne KG, Ault GT, Strumwasser AM. Long-term follow-up of Fournier's Gangrene in a tertiary care center. J Surg Res 2016;206(1):175-81. doi: 10.1016/j.jss.2016.06.091.

4. Bednarek M, Drożdż W. Rzadki przypadek rozleglej martwicy Fourniera w przebiegu ropnia okołoodbytniczego. Przegl Lek 2008;65:410-12.
5. Gołąb A, Sprogis J, Kaczmarek A, Sikorski A. Zgorzel Fourniera - obserwacja trzynastu chorych. Urol Pol 2001;54:4.

6. Hohendorff B, Seyler S, Naik M, Biber F, Franke J. Amputation of the hand due to necrotizing fascitis: a case report. Handchir Mikrochir Plast Chir 2015;47:71-4.

7. Żyluk A, Piotuch B. Rozległa ropowica paciorkowcowa kończyny górnej po otarciu naskórka ręki, powikłana posocznicą - opis przypadku. Chir Narzadow Ruchu Ortop Pol 2015;80:207-13.

\section{KOMENTARZ}

Zgorzel Fourniera po raz pierwszy opisał Baurienne, a jej nazwa związana jest z Jeanem Alfredem Fournierem - wenerologiem, który przedstawił 5 przypadków w 1883 r. Zgorzel Fourniera jest ostrym, szybko postępującym, infekcyjnym martwiczym zapaleniem powięzi krocza, okolic zewnętrznych narządów płciowych i tkanek okołoodbytniczych, najczęściej występującym u mężczyzn, ale również u kobiet i dzieci. Spostrzeżenia Autorów w przypadku tej choroby o dużej śmiertelności są bardzo cenne dla odpowiedniego leczenia. Jak piszą Autorzy: „Opisywany przypadek jest interesujący przez swoje podobieństwo do ropnia odbytowego (...), a faktycznie było to martwicze zapalenie tkanek miękkich okołoodbytniczych spowodowane bakterią E. coli", a ponieważ najczęściej jest to związane z działalnością kliniki urologicznej, gdzie chorych z zespołem Fourniera leczy się najwięcej, dlatego pokazanie tak nietypowego początku łagodnej zgorzeli Fourniera jest cennym doniesieniem medycznym. W ciężkich przypadkach zespołu Fourniera, mimo zastosowania wielokrotnie radykalnej interwencji chirurgicznej i antybiotykoterapii dożylnej o szerokim spektrum, nie zawsze dochodzi do wyleczenia, a śmiertelność jest wyjątkowo duża.

prof. dr hab. n. med. Tadeusz Sulikowski 